2004, 20(3), 388-404

\title{
A study of educational technology project management in Australian universities
}

\section{John Kenny}

RMIT University

The development of quality learning materials using new technology requires the use of a wide range of skills beyond those possessed by many academic staff. Obtaining quality online learning experiences may require academics to work in teams with others who provide educational design support and technical expertise. The effective management of a team to produce the desired outcomes to a specified quality standard has typically been the responsibility of the project manager.

Applying standard project management techniques to teams containing highly independent academics and teachers in an educational environment presents certain cultural and procedural difficulties. This paper reports on some of the current literature on this issue and relates it to the results of a survey of 25 project managers in Australian universities. Parallels are made with the literature of innovative projects.

\section{Introduction}

Project management has evolved as a means of effectively managing human and other resources gathered to deliver a pre-determined product or service with specified technical requirements, time scale, budget and quality standards. In classic project management, a series of standard techniques and processes are applied, to bring projects in 'on time and within budget'. These techniques are used effectively across a wide range of industries.

Increasingly, with the use of new technologies in the development and delivery of educational material, these techniques are being applied to the production of courseware. For example, Kenny and McNaught (2000) described how teams of specialists work together on educational development activities for online learning, and the Learning and Teaching Strategy of the Open University in the UK proposes that course leaders 
need to develop project management skills to increase the speed and efficiency of course development projects.

However, this move to use management processes in the university sector can lead to problems. Phelps, Ledgerwood \& Bartlett (2000) recounted their experiences as project managers leading teams of academic staff through a project management process designed to adapt teaching and learning practices to the use of new technology. They concluded that the "introduction of project management methodology into the academic environment creates cultural and procedural dissonance."

Phelps et al (2000) questioned the application of project management processes to curriculum development in an educational institution. They pointed to several problems, including the cultural aspects of the educational environment, and the independent nature of academic work. However, they still saw a role for aspects of the project management process, "particularly with regards to infrastructure."

Bates (2000) felt that the main advantage of the project management approach to educational projects is the efficient allocation and use of scarce resources. He also noted a tension between the classical project management approach and the nature of academic work. In an attempt to overcome this problem, he advocated a looser approach to project management which:

...does not attempt to quantify every activity on a micro level. The project manager and the academic have a good deal of freedom to move resources around and adjust schedules to meet the reality of academic life. ...

However at the end of the day, there still has to be a course developed and deadlines met. (Bates, 2000, p.73)

This paper explores the suitability of project management processes for educational projects and the ways that they are structured in universities. It considers project management per se and draws on the literature and a survey of project managers to identify suitable approaches for the effective management of educational projects.

\section{The nature of project management}

The Project Management Institute (PMI) is based in the United States and was founded in 1969. PMI has almost 100,000 members worldwide and publishes A Guide to the Project Management Body of Knowledge, PMBOK Guide (2000), wherein project management is defined as "the application of knowledge, skills, tools, and techniques to a broad range of activities in order to meet the requirements of a particular project." 
Shenhar and Dvir (1996), Sheasley (1999) and Lester (1998) noted that project teams involved in innovation operated with high levels of uncertainty. The reduction of uncertainty was achieved by setting up self managed project teams with open communication, looser management structures, and an iterative approach to learning.

Mintzberg (1994) and De Wit and Meyer (2000) associated uncertainty with radical strategic change. Rogers (1995) linked the degree of uncertainty associated with implementing an innovation to the "amount of knowledge" it required of staff to adopt it. The level of uncertainty increased with the degree of change expected of the individuals.

The more radical an innovation, indexed by the amount of knowledge that organisational members must acquire in order to adopt, the more

uncertainty it creates and the more difficult its implementation. (Rogers, 1995, p.397)

Ehrmann (2001) also identified learning as a key component of "transformative change", and noted that when technology was involved in such change, "the stakes and risks are even higher than normal." Bates (2000) explained how the implementation of a technological innovation in the educational sector has implications for teaching practice:

Teaching with technology requires a high skill level and this necessitates training not just in technological matters but also in educational practice. Training needs to be embedded in the course development process and the project management model can assist this. (Bates, 2000, p.3)

Where Bates (2000) referred to "training", Kenny and McNaught (2000) used the term "professional development":

Many staff may need professional development in some of these areas to go along with the training and professional development associated with the use of new learning technologies themselves. ... Teachers may therefore feel uneasy on two accounts; they are learning new skills while operating within an unfamiliar environment.

Traditionally, the project management process itself does not distinguish between different types of projects; the choice of which particular processes will be employed in any situation is left to the judgment of the individual project manager. However, Kenny (2003b) and Kenny (2002) proposed that projects can be distinguished on the basis of their scope and the degree of uncertainty associated with them. He developed a typology to classify projects on these criteria. Some illustrative examples using this typology are shown in Table 1. 
Table 1: Examples of project categories

\begin{tabular}{|c|c|c|}
\hline Project category & Description & Examples \\
\hline $\begin{array}{l}\text { Category One } \\
\text { Broad radical strategic } \\
\text { change or innovation. }\end{array}$ & $\begin{array}{l}\text { Strategic Projects } \\
\text { with high to very } \\
\text { high levels of } \\
\text { uncertainty and } \\
\text { wide organisational } \\
\text { impact. }\end{array}$ & $\begin{array}{l}\text { - } \\
\text { Implemen organisational re-structure. } \\
\text { organisational of system wide } \\
\text { innovation. } \\
\text { - Implementation of a new strategic } \\
\text { direction or policy for the } \\
\text { organisation with significant } \\
\text { implications for practice. }\end{array}$ \\
\hline $\begin{array}{l}\text { Category Two } \\
\text { Localised radical } \\
\text { change or innovation. }\end{array}$ & $\begin{array}{l}\text { Projects with high to } \\
\text { very high levels of } \\
\text { uncertainty but low } \\
\text { organisational } \\
\text { impact. }\end{array}$ & $\begin{array}{l}\text { - Preliminary pilot study related to } \\
\text { a category one project. } \\
\text { - Development of a new program. } \\
\text { Radical change or innovation } \\
\text { project initiated at the work unit } \\
\text { level }\end{array}$ \\
\hline $\begin{array}{l}\text { Category Three } \\
\text { Broad incremental } \\
\text { change or continuous } \\
\text { improvement activity. }\end{array}$ & $\begin{array}{l}\text { Projects with low } \\
\text { levels of uncertainty } \\
\text { but wide } \\
\text { organisational } \\
\text { impact. }\end{array}$ & $\begin{array}{l}\text { Routine improvements to an } \\
\text { existing subject or course. } \\
\text { - Systemic quality assurance } \\
\text { process }\end{array}$ \\
\hline $\begin{array}{l}\text { Category Four } \\
\text { Localised incremental } \\
\text { change or continuous } \\
\text { improvement activity. }\end{array}$ & $\begin{array}{l}\text { Projects or activities } \\
\text { with low levels of } \\
\text { uncertainty and low } \\
\text { organisational } \\
\text { impact. }\end{array}$ & $\begin{array}{l}\text { - Routine improvements to an } \\
\text { existing subject or course. } \\
\text { - Quality assurance activity }\end{array}$ \\
\hline
\end{tabular}

Thus, new learning technologies require staff not only to acquire skills in using the technology in a learning environment, but also to re-consider its implications for educational design and teaching practices. Bates (2000, p.3) suggested that project management can assist the learning process by ensuring that the resources needed are provided. It seems that the value of project management in cases where there is a great deal of uncertainty, is not to micro-schedule, enforce strict deadlines and outcomes, but to ensure that adequate resources are provided to enable the project to proceed effectively, and to maximise the opportunities for learning and growth inherent in projects of this nature.

Bates (2000) and Phelps et al. (2000) are consistent with Shenhar and Dvir (1996), Lester (1998) and Sheasley (1999) in their calls for looser project management models. Goodyear (2001) proposed a project management model designed for "development ideas". It had six stages: Feasibility, Requirements Analysis, Design, Implementation and Evaluation. Goodyear claimed that the focus of this model is to justify and plan the infrastructure to support learning, as well as to support the project. Thus, 
on a macro level, project management can link into organisational processes ensuring adequate resourcing is provided, as called for by Kenny and McNaught (2000).

\section{Embedding learning into projects}

The typology presented by Kenny (2002) indicates that projects with higher levels of uncertainty (Category One and Category Two) need to be set up and managed differently from conventional projects, with the emphasis on self managed teams and open communication to maximise learning. When independent professionals such as academics and teachers are involved in an innovative project, the project management process needs to support practices that enable professional growth and learning. Action research and action learning (ALAR) are widely acknowledged processes for this purpose (Zuber-Skerritt, 2000; Elliot, 1991; McGill and Beaty, 2001; Biggs, 1999).

Senge (1990) also discusses the importance of reflection and inquiry processes for promoting a learning organisation. He talks of 'mental models' that every manager possesses and how these must be brought to awareness and then examined critically. In order to effectively bring about a change in practice, the conditions for enabling professional growth must be addressed.

Rogers (1995) described "social construction" as the single most important part in the adoption of an innovation, as it enables the practitioners to learn and to reduce the level of uncertainty. However, Elliott (1991) observed that time for reflection is often given a low priority in organisations.

Integral to the ALAR process is reflection on learning, sharing the learning with others and applying the learning to improve the next iteration. Zuber-Skerritt (2001) noted that the effective adoption of ALAR requires support of senior management in organisation. Lester (1998) also included this in his list of organisational success factors for innovative projects.

In summary, the literature referred to supports a project management process for innovative educational projects, based on self managed development teams working within an iterative process of learning. Action learning as a process fits very well into this paradigm and is an accepted model for the growth of professional practitioners. The operation of action learning requires a culture in the organisation which is supportive of risk taking and entrepreneurial activity. 


\section{Survey of project managers}

The survey presented here was designed and circulated to get information about the nature of project management processes used in tertiary institutions. It was initiated in 2001 as part of a wider doctoral study, in response to a perceived resistance by certain academic staff, to the use of a project based approach to educational development projects. The design enabled the collection of both quantitative data (using a Likert type scale) and qualitative data using free text responses. It was provided, for the convenience of the respondents, as an online questionnaire and as an email attachment. The target audience for the questionnaire was practitioners within the tertiary sector who had managed educational projects involving new technology within the last three years.

The responding group included some individuals contacted directly because they were known to be involved in managing these types of projects. Another group of respondents came from participants contacted via a posting in the Australasian Society for Computers in Learning in Tertiary Education (ASCILITE) discussion forums, 'Development Units' and 'Research'.

The survey aimed to identify any peculiarities associated with the tertiary education environment in relation to the management of projects. It queried the project managers about certain aspects of their work as project managers, and how this related to other duties they had. In particular, the survey asked about:

- the extent of their experience, and qualifications in project management.

- the state of any institutional project management processes and guidelines available to them

- the supports offered to them and their team in their role.

- the levels of control and autonomy they had over the project.

- the proportion of their time devoted to the project management role.

- what worked well, what blocks they encountered, and what they would do better in future projects.

The combination of quantitative and qualitative data enabled patterns to be investigated as well as providing a richer description of issues which emerged. The quantitative data was analysed using statistical methods. Responses to the free text questions were considered using a grounded analysis. A series of categories emerged from the data and these were tallied to gauge the frequency of each. 


\section{Data summary and analysis}

Twenty-five responses were received from project managers working in sixteen different tertiary institutions within Australia, as well as one from a consulting firm which had done project work for tertiary institutions. The only requirement was having recent experience in managing educational projects involving new technology.

\section{Background and support}

The group as a whole was very experienced. The majority $(88 \%)$ of the respondents selected either "totally agree" or "agree" to the statement that they had adequate prior experience with managing educational projects using new technology.

Table 2: Relevant prior experience

\begin{tabular}{|l|c|c|}
\hline \multicolumn{1}{|c|}{ Experience and qualifications } & Number & Percentage \\
\hline Teaching experience & 20 & $80 \%$ \\
\hline Prior experience managing technology projects & 18 & $72 \%$ \\
\hline Technical skills & 14 & $56 \%$ \\
\hline Content expertise & 10 & $40 \%$ \\
\hline Project management qualifications & 7 & $28 \%$ \\
\hline Course team leader & 4 & $16 \%$ \\
\hline
\end{tabular}

Table 2 summarises the background experience or qualifications which the respondents felt was relevant to their role in leading educational projects using new technology. $80 \%$ of the respondents felt that their teaching experience was relevant. $72 \%$ of the respondents selected prior experience with managing educational projects using new technology, and 56\% identified specific technical skills as relevant. It is interesting that only 7 $(28 \%)$ selected formal project management qualifications as relevant to their role in leading these projects. This point will be addressed again later, but may relate to the nature of these projects.

Table 3 shows the range of educational projects on which the respondents had worked. According to the typology in Kenny (2002), all of the projects would be considered category two projects, consisting of localised change or innovation.

When asked to select from a list of supports offered to them in their roles as project managers (Table 4), the largest area of support selected was "process documentation templates" by $16(64 \%)$ of the respondents. It is interesting to note that less than half $(48 \%)$ of the respondents felt that 
they had adequate funding for the projects, and only $9(36 \%)$ felt that they had senior management back-up. This last point was clearly identified in the literature as a key success factor for projects by Alexander et al (1998) and Lester (1998). The fact that only seven (28\%) of respondents identified "training specific to the role" as a support offered to them as project managers, and only $5(20 \%)$ identified "mentoring by an experienced project manager", indicates that most respondents carry out their role without formal qualifications in project management and rely on process documentation or their prior experience.

Table 3: Range of project types reported by respondents as worked on in last three years

\begin{tabular}{|l|c|}
\hline \multicolumn{1}{|c|}{ Project type } & No. respondents \\
\hline Website development & 5 \\
\hline CD & 8 \\
\hline Software & 13 \\
\hline Online course design, development & 3 \\
\hline Simulations, animations and interactive games & 2 \\
\hline Video & 3 \\
\hline Consultancy & 2 \\
\hline Management & \\
\hline
\end{tabular}

Table 4: Forms of support reported

\begin{tabular}{|l|c|c|}
\hline \multicolumn{1}{|c|}{ Forms of support } & Number & Percent \\
\hline Process documentation templates & 16 & $64 \%$ \\
\hline Technical support & 11 & $44 \%$ \\
\hline Adequate funding & 12 & $48 \%$ \\
\hline Time release from other duties & 10 & $40 \%$ \\
\hline Senior management back-up & 9 & $36 \%$ \\
\hline Training specific to the role & 7 & $28 \%$ \\
\hline Mentoring by an experienced project manager & 5 & $20 \%$ \\
\hline Other & 3 & $12 \%$ \\
\hline
\end{tabular}

Only six $(24 \%)$ of the respondents saw wider institutional issues as having a direct influence on their projects. This indicates that whilst some of the projects were initiated as a part of some organisational strategic push, the majority were concerned with the application of new technological approaches to localised teaching and learning projects. Eleven respondents $(44 \%)$ agreed that their institution provided clear project management guidelines, and $15(60 \%)$ felt that they were offered sufficient support to carry out their project management functions. 
The multi disciplinary nature of the project teams was evident through the range of roles reported in the projects. Aside from the project manager, over $80 \%$ of the projects included educational design, content and graphic design expertise, while web programming expertise was reported in $68 \%$ of projects.

\section{Autonomy}

While $80 \%$ of respondents agreed that they had sufficient autonomy to work effectively as project managers, only $60 \%$ agreed that they were offered sufficient support by their institution or department to carry out their project management functions. The survey probed further on the issue of autonomy in their role as a project manager, in particular in relation to the selection of human resources for their projects, the budget for their projects, and the timelines (Table 5). Just over half (52\%) agreed that they had sufficient autonomy over each of these key aspects of their projects: human resources, budget and timelines. When the data was examined more closely across the three aspects, $20 \%$ of the respondents reported a lack of autonomy over any of the three aspects, and a further 8 $(32 \%)$ reported insufficient autonomy in at least two of the aspects. This meant that, in effect, $52 \%$ of the project managers surveyed had little or no control over two of the three key aspects of their projects.

Table 5: Responses to the statement "I had sufficient autonomy over..."

\begin{tabular}{|l|c|c|c|c|c|c|}
\hline \multicolumn{1}{|c|}{ Autonomy rating } & \multicolumn{2}{c|}{$\begin{array}{c}\text { Human } \\
\text { resources }\end{array}$} & \multicolumn{2}{c|}{ Budget } & \multicolumn{2}{c|}{ Timelines } \\
\hline Totally Agree/Agree & 13 & $52 \%$ & 13 & $52 \%$ & 13 & $52 \%$ \\
\hline Totally Disagree/ Disagree & 11 & $44 \%$ & 10 & $40 \%$ & 11 & $44 \%$ \\
\hline
\end{tabular}

When asked to select the time fraction of their work which was devoted to managing projects, the results, shown in Table 6, indicate that $20 \%$ selected full time, $40 \%$ selected time fractions 'between $20 \%$ and $80 \%$ ', and $36 \%$ selected 'less than $20 \%$ '.

Table 6: Estimated time fraction working as a project manager

\begin{tabular}{|l|c|c|}
\hline \multicolumn{1}{|c|}{$\begin{array}{c}\text { Estimated time fraction as } \\
\text { project manager }\end{array}$} & Number & Percentage \\
\hline Less than 20\% & 9 & $36 \%$ \\
\hline Between 20\% and 40\% & 4 & $16 \%$ \\
\hline Between 40\% and 50\% & 3 & $12 \%$ \\
\hline Between 50\% and 80\% & 3 & $12 \%$ \\
\hline Between 80\% and 90\% & 1 & $4 \%$ \\
\hline Full time & 5 & $20 \%$ \\
\hline
\end{tabular}


This means that $64 \%$ estimated that less than $50 \%$ of their time was allocated to project management. Lester (1998) stated that members of the 'Venture Teams' set up for innovative projects needed to have over $50 \%$ of their time working on the project, otherwise they were classed as 'resources' for the team to draw on. On this basis, $64 \%$ of the project managers would not be considered members of the project team!

\section{Roles}

The range of roles involved in the projects reported by the respondents is revealed in Table 7 . It indicates the multi-disciplinary nature of the project teams. The fact that project teams perform the work underscores the need for appropriate team based processes and resourcing to ensure that they can function effectively.

Table 7: Specific roles involved in the projects

\begin{tabular}{|l|c|c|}
\hline \multicolumn{1}{|c|}{ Identified roles involved in the projects } & Number & Percentage \\
\hline Project manager & 25 & $100 \%$ \\
\hline Educational designer & 24 & $96 \%$ \\
\hline Content expertise & 21 & $84 \%$ \\
\hline Graphic designer & 20 & $80 \%$ \\
\hline Web programmer & 17 & $68 \%$ \\
\hline Other & 11 & $44 \%$ \\
\hline
\end{tabular}

\section{Analysis of the qualitative data}

The free text response questions allowed the respondents to explain in their own words any particular aspects of their projects which had worked well, to identify the obstacles they encountered, and also to suggest what they would do differently for a future project. The text responses were analysed and grouped into three aspects: Project Team Processes, Project Resources and Project Management Issues. These aspects were also further divided into eleven sub groups. A tally was kept for each and the results are shown in Table 8 .

If we consider the raw number of times a particular issue arose as an indicator of the importance of the issue for the respondents, whether or not it was mentioned as an obstacle, or as some thing that worked well, this gives a means for estimating what the respondents saw as important factors in their projects. These are given in the totals column. For example, in Table 8, "Project management issues" received $36(13+23)$ mentions in the totals, indicating its significance to the effective management of the projects, in the opinion of the respondents. "Project team processes" were mentioned a total of twenty five times $(16+9)$. The highest ratings $(8$ and 
above) were in order: communication processes, project management processes, human resources and technical support, adequate time release, and support of senior management.

Table 8: Respondents' comments on what worked well and what the obstacles were

\begin{tabular}{|c|c|c|c|}
\hline $\begin{array}{c}\text { Aspects of the projects mentioned by } \\
\text { respondents }\end{array}$ & $\begin{array}{c}\text { What } \\
\text { worked well }\end{array}$ & $\begin{array}{c}\text { Major } \\
\text { obstacles }\end{array}$ & Totals \\
\hline Project team processes & 9 & 15 \\
\hline Communication, meetings & 9 & 6 & 5 \\
\hline Identified team roles & 3 & 2 & 5 \\
\hline Staff development approach & 4 & 1 & 25 \\
\hline Total & 16 & 9 & 9 \\
\hline Project resources & 1 & 8 & 10 \\
\hline Adequate time release & 5 & 5 & 2 \\
\hline Human resources and technical support & 0 & 2 & 21 \\
\hline Institutional processes and policies & 6 & 15 & 6 \\
\hline Total & & 3 & 6 \\
\hline Project management issues & 3 & 5 & 8 \\
\hline Project manager & 1 & 7 & 3 \\
\hline Realistic timelines & 1 & 6 & 13 \\
\hline Adequate budget & 1 & 23 & 36 \\
\hline Tupport of senior management & 7 & 13 &
\end{tabular}

\section{Success factors}

The key features associated with successful projects mentioned by the respondents included: an identified team with shared goals, clearly defined roles and good communication:

Having a multi-disciplinary team work in a coordinated effort on a set of shared objectives is the most beneficial aspect of the projects.

The documentation is quite specific enabling all team members some shared consistent information about the project and the roles and responsibilities of each team member. It also documents timelines and deliverables and has sign off points outlined clearly. Regular project meetings are held weekly or fortnightly which also enables timelines and milestones to be continually monitored

The projects that work well have a very dedicated Project Leader/manager, who is able to bring all of the elements (people, resources) together into a coherent whole. When all members of the project team can meet, especially in the early phases of a project, the project has much more coherence. I have worked on two such projects. 
We have good systems in place for project management and are flexible in our approach so that we adapt to the needs of the project and the client

Enthusiasm of the staff was also mentioned and this was linked to staff development, engagement and support at all stages of the project and during implementation.

Much of the success of the project is due to the enthusiasm of academic staff to be involved in the online development - it was very much seen as a staff development opportunity. The academics are engaged in the development of their units at every stage and support from the project continues throughout the delivery of the units.

The projects that have been the most successful however have been those where the faculty member who has taken on the technology has been willing to learn and do a large part of the work themselves and where they have been willing to look at new ways of doing things. I provide them with the training and support they need to use the technology and they go ahead and do it.

Well-led projects using flexible team approaches, ownership, involvement and enthusiasm of academic staff were common factors identified with successful projects, so clearly project management strategies need to be employed which encourage these.

Results quoted in Table 6 indicate that many of the staff who manage educational projects in universities have significant amounts of their time taken up with other duties. This could lead to possible conflicts in prioritising of time and resources, as indicated by some of the comments in relation to the obstacles encountered. It appeared to apply to not only the project managers but also the academics.

Juggling so many projects. I am spread thin across a number of projects.

Content provision is our single biggest bottleneck. Time always short as we have too many projects.

Expanding on the resources issue, there appeared to be a lack of awareness by the organisational managers of what is involved in educational technology development projects:

Inadequate resources allocated to the project initially (through not understanding the requirements of technology-based projects)

Sufficient time to allow all members of a project team to meet regularly. Lack of understanding of the time commitment required to achieve effective outcomes from senior management 
Organisational practices seemed to underlie most of the obstacles identified by the respondents in the university environment, with staff having to juggle competing priorities. Because of their role in the allocation of resources, it would seem that organisational managers need to be more aware of the demands that these projects place on staff.

Time release for content experts to be able to conceptualise and develop their part of the project. Juggling human resources between competing projects not enough skilled staff (in the technical areas) to do the job

Limited time and motivation for improved communication and

cohesiveness of team members when they all report to different line managers. Human and other resources not explicitly allocated to the project prior to commitment to it.

Time to work effectively on all projects. Access to sufficient, appropriate people with the right technical expertise. Sufficient time to allow all members of a project team to meet regularly. Lack of understanding of the time commitment required to achieve effective outcomes from senior management.

The competing demands upon staff time obviously could lead to competing loyalties and priorities affecting the cohesion of the project team. The view of academics as the "content suppliers" presented some problems for project managers as it did not necessarily lead to the academics feeling fully engaged with the project:

It has often been seen as an IT initiative - academics often expressed

concern at being used as content suppliers and IT using 'their' online units to build up the IT empire.

The involvement of the team members has already been highlighted as a success factor and the quotation above emphasises this point from the negative. Feedback indicated that the staff working on projects were usually employees of the university and that involvement in the project is added to their list of duties. This would explain why salaries of the project staff was not a major concern of the respondents. This, along with the tendency for staff to work on several projects, or have a range of other duties in addition to their project responsibilities, distinguishes projects in this environment from the classical project management model, where the project manager controls the budget and has the authority to hire and fire staff.

The need to fully scope a project at the outset was seen as a success factor also. It is important that the management and the participants in a project are fully aware of the demands a project will place on staff prior to the project beginning. This process also linked to assessing the feasibility of projects and to ensuring they are adequately resourced. 
In all projects, I now spend a good deal of effort in the planning and analysis stages of any project before committing a great deal of resources in product development The second most important factor is to ensure the content expert understands the parameters of their roles and time involved to realise the outcomes required and the funding to ensure this time is possible.

From this data, it is clear that management has to be fully aware of the needs of educational development projects and to ensure that they are set up within the parameters of the organisational budgeting and planning processes, so that they are adequately resourced and funded. Clearly, there is a need for an organisational process to coordinate the range of projects which are underway and to ensure this happens.

The evidence here suggests that the competing workload demands on academics and the structuring of some projects, which reduces opportunities for learning, might be a more pertinent reason for the "dissonance" reported by Phelps et al (2000) than some inherent resistance to project management. The survey indicated a general under-resourcing of projectss, evident in a widely reported lack of time to devote to tasks, because of competing demands placed on staff.

Ehrmann (2001), Kenny and McNaught (2000), Kenny (2001), Laurillard (1997) and Bain (1999) all pointed out that, because of resource requirements of these projects, project management processes must be embedded within organisational processes. In project management terms, this amounts to the need for realistic scoping of requirements for these projects to be carried out 'up front', with sign off and approval by management for the level of resourcing required. The level of resourcing must acknowledge the exploratory nature of these projects and the needs for staff to share ideas and construct meaning.

\section{Summary}

The survey results give a 'pen picture' of a typical educational technology project manager in a university. As we have seen, tertiary educational environments present certain cultural and work practice issues that do not necessarily fit with a classical project management approach. Project managers need to be aware of these issues, particularly in relation to projects involving large amounts of change and innovation.

On the basis of this sample of respondents, the typical project manager would have the following characteristics:

- have a teaching background and some acquired technical skills.

- have no formal training in project management practice. 
- have other duties aside from their project management role, for at least $50 \%$ of their time.

- work in an institution which has few formal project management guidelines and little formal evaluation of the effectiveness of the projects or processes.

- work in an institution where limited processes exist to share the learning in a project with others.

- have little control over the budget, human resources or timelines for the projects, and little direct authority over the project team.

- often encounter a shortage of resources in terms of technical expertise, or time for content experts to develop materials.

\section{Conclusions}

Many projects in a tertiary education environment lend themselves to a classical project management approach, but those that involve changes in the practices of academics or teachers introduce high levels of uncertainty. Projects of this nature need to be structured to enable learning, and must acknowledge the autonomous nature of academic work. Activities such as course re-developments, which employ new approaches to learning, for example using new technology, have many of the characteristics of innovative projects. They must be set up to enable open communication channels, loose management structures and professional development opportunities. Action learning must be an integral part of the project management process as it provides an opportunity for the staff concerned to share ideas and reflect on learning.

The value of project management in this environment is not to micromanage academics, but to ensure that the resources and conditions that will enable the project to be successful are identified early in the set up stages.

The project manager, in this environment, has more of a coordination and facilitation role, rather than a classical management role. The aim is to ensure that academic staff are involved in the project, are supported in the development and implementation phases, and that the project is evaluated and the learning is shared with the organisation.

Treating academics as "content experts" with little other involvement in a project is unlikely to develop the degree of understanding, ownership and capability the staff will need to be able to update and maintain the materials beyond the immediate life of the project. 
The project management process has to be embedded within the organisational planning processes and in tune with the natural rhythms of the organisation. The support of senior management is important and can be demonstrated by the provision of adequate resources based on a thorough project scoping process prior to a decision to proceed. The key is for the organisational culture, infrastructure and resourcing to operate in a way which will enable these projects to proceed effectively.

\section{References}

Alexander, S., McKenzie, J. \& Geissinger, H. (1998). An evaluation of information technology projects for university learning. Committee for University Teaching and Staff Development. Canberra: Australian Government Publishing Service.

Bain, J. D. (1999). Inroduction to the special issue: Learner-centred evaluation of innovation in higher education. Higher Education Research \& Development, 18(2), 165-172.

Bates, A. W. (2000). Managing Technological Change. Strategies for College and University Leaders. 1st Edition. Jossey-Bass. San Francisco.

De Wit, B. \& Meyer, R. (1999). Strategy Synthesis: Resolving Strategy Paradoxes to Create Competitive Advantage. London, International Thomson Business Press.

Ehrmann, S. (2001). Transformative Assessment of Educational Uses of Technology. Early Glimpses.

http: / / www.tltgroup.org/resources / F_Eval_Cases/Transform_three.html

Elliott, J. (1991). Action Research for Educational Change. Buckingham: Open University Press.

Goodyear, P. et. al. (2001). Effective networked learning in higher education: Notes and guidelines. Networked Learning in Higher Education Project. Lancaster University, England. http:/ / csalt.lancs.ac.uk/jisc/Guidelines_final.doc

Kenny, J. (2003a). A research based model for managing strategic educational change and innovation projects. Research and Development in Higher education, Vol. 26, pp.333-342. Proceedings of HERDSA Conference (2003), Christchurch, New Zealand. [verified 23 Aug 2004]

http: / / surveys.canterbury.ac.nz/herdsa03/pdfsref/Y1102.pdf

Kenny, J. (2003b). Project management for strategic innovation and change in an organisation. Project Management Journal, 34(1), 43-53.

Kenny, J. (2002). Managing innovation in educational institutions. Australian Journal of Educational Technology, 18(3), 359-376. http:/ / www.ascilite.org.au/ajet/ajet18/kenny.html

Kenny, J. (2001). Where academia meets management: A model for the effective development of learning materials using new technology. In Meeting at the Crossroads. pp.327-334. Proceedings 18th ASCILITE Conference, Melbourne. http:/ / www.ascilite.org.au/conferences/melbourne01/pdf/papers/kennyj.pdf 
Kenny, J. and McNaught, C. (2000). Promoting quality outcomes in higher education using new learning technologies: Processes and plans at RMIT. In R. Sims, M. O'Reilly \& S. Sawkins (Eds), Learning to choose. Choosing to learn, pp. 655-664. Proceedings of the 17th Annual ASCILITE Conference, Southern Cross University, Coffs Harbour, 9-14 December.

http: / / www.ascilite.org.au/conferences / coffs00/ papers/john_kenny.pdf

Laurillard, D. (1997). Applying systems thinking to higher education. Position paper, Milton Keynes: Open University.

Lester, D. H. (1998). Critical success factors for new product development. Research Technology Management, 41(1), 36-43.

McNaught, C., Kenny, J., Kennedy, P. \& Lord, R. (1999). Developing and evaluating a university-wide online Distributed Learning System: The experience at RMIT University, Educational Technology and Society, 2(4), http:/ / ifets.massey.ac.nz/periodical/vol_4_99/mcnaught.html

Mintzberg, H. (1994). The Rise and Fall of Strategic Planning. UK: Prentice-Hall International.

Open University Learning and Teaching Strategy (2001). http: / / www.open.ac.uk/pdg/lto/p3_2.shtml, http://www.open.ac.uk/pdg/lto/pics/d14968.doc

Phelps, R., Ledgerwood, T. \& Bartlett, L. (2000). Managing the transition to online teaching: The role of project management methodology in the learning organisation. Paper presented at the Moving Online Conference, Gold Coast, Australia, 18-19 August. [menu] http: / / www.scu.edu.au/schools / socialsciences / dds / ?menu=95

PMBOK (2000). A Guide to the Project Management Body of Knowledge. 2000 edition. Project Management Institute. http:/ / www.pmi.org/

Rogers, E.M. (1995). Diffusion of Innovations. 4th Edition. The Free Press, Simon \& Schuster, New York.

Senge, P. M. (1990). The Fifth Discipline: The Art and Practice of the Learning Organisation. Sydney: Random House.

John Kenny

Professional Development

RMIT Learning Technology Services

Melbourne, Victoria

Phone: +61 399253545

Email: john.kenny@rmit.edu.au 